\title{
Inland Ertebølle Culture: the importance of aquatic resources and the freshwater reservoir effect in radiocarbon dates from pottery food crusts
}

\section{Bente Philippsen ${ }^{1}$ and \ohn Meadows ${ }^{2}$}

Cite this as: Philippsen, B. and Meadows, J. (2014), Inland Ertebølle Culture: the importance of aquatic resources and the freshwater reservoir effect in radiocarbon dates from pottery food crusts. 'Human Exploitation of Aquatic Landscapes' special issue (ed. Ricardo Fernandes and John Meadows), Internet Archaeology 37. http://dx.doi.org/10.11141/ia.37.9

1. AMS 14C Dating Centre, Department of Physics and Astronomy, Aarhus University. Ny Munkegade 120, 8000 Aarhus C, Denmark \& Museum Lolland-Falster, Gl. Badevej 2E, 4970 Rødbyhavn, Denmark.

2. Zentrum für Baltische und Skandinavische Archäologie, Stiftung Schleswig-Holsteinische Landesmuseen, Schloss Gottorf, 24837 Schleswig, Germany \& Christian-Albrechts-Universität zu Kiel, Leibniz-Labor für Altersbestimmung und

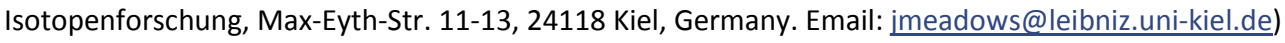

Key words: Mesolithic, Ertebølle culture; radiocarbon dating; freshwater reservoir effect; stable isotopes; prehistoric pottery; food crust; palaeodiet; palaeocuisine

This issue has been funded by the Graduate School "Human Development in Landscapes", University of Kiel with additional funding from the Institute for Ecosystem Research, University of Kiel and the Centre for Baltic and Scandinavian Archaeology, Schloss Gottorf.

(C) Author(s). Except where otherwise noted, content from this work may be used under the terms of the Creative Commons Attribution 3.0 Unported licence, which permits unrestricted use, distribution, and reproduction in any medium, provided that attribution to the author(s), the title of the work, the Internet Archaeology journal and the relevant URL/DOI is given. 


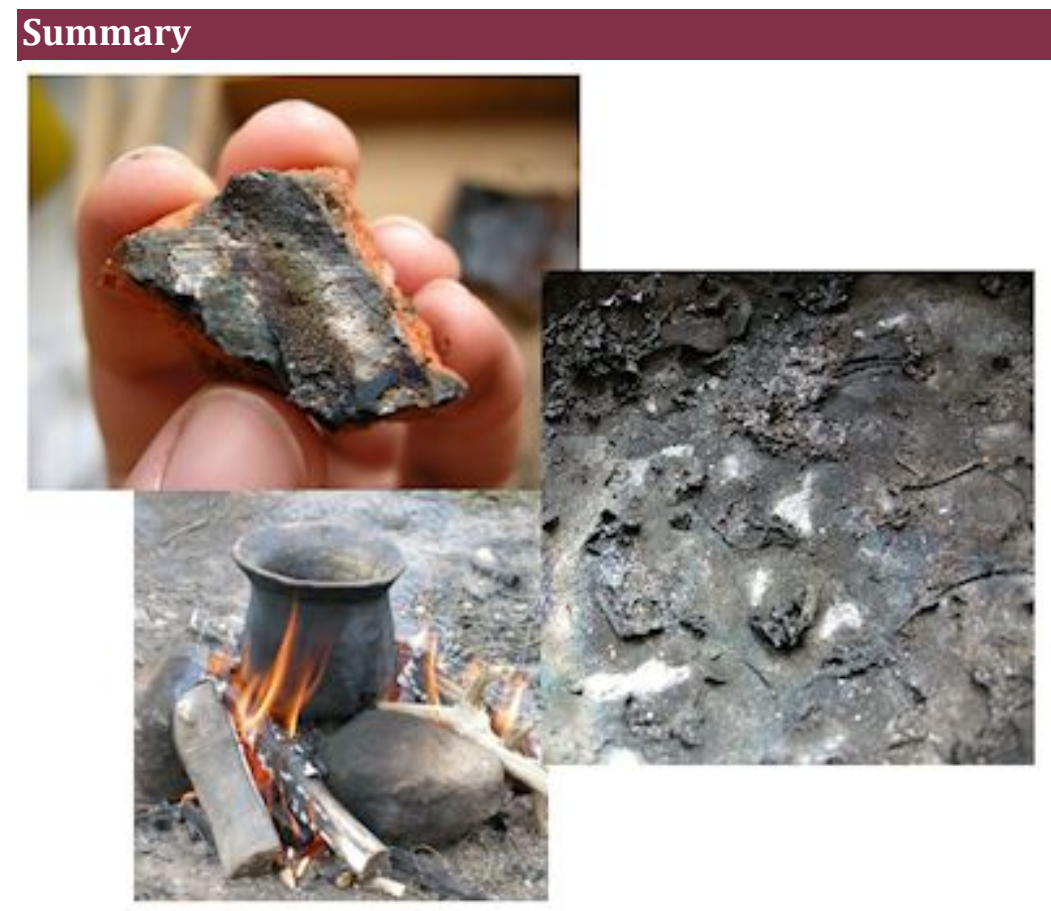

The Ertebølle culture is a late Mesolithic hunter-gatherer-fisher culture in southern Scandinavia, northern Germany and Poland. Archaeological finds as well as scientific analyses of humans and their artefacts indicate the great importance of aquatic resources, both marine and freshwater, to Ertebølle subsistence.

In northern Germany, modern freshwater fish samples can have very high apparent radiocarbon ages (up to 3000 years). If such dramatic 'freshwater reservoir effects' also existed during the late Mesolithic, they could lead to artificially old radiocarbon dates for the bones of Ertebølle humans and domestic dogs, and for carbonised food crusts on cooking pots. Conversely, if we can demonstrate radiocarbon age 'offsets' in such samples, we can often attribute them to the exploitation of freshwater food resources.

This article discusses methods of identifying freshwater resources in prehistoric pottery, including radiocarbon reservoir effects. We consider the results of radiocarbon, stable isotope and elemental analyses of food crusts on prehistoric pottery from four sites in the Alster and Trave valleys: Kayhude, Schlamersdorf, Bebensee and Seedorf. 


\section{Introduction}

\subsection{Freshwater resources in the Ertebølle culture}

The culture discussed in this article, the late Mesolithic Ertebølle (EBK) culture, is famous for its large coastal shell middens. In the past, it was assumed to be a purely coastal phenomenon (Gjessing 1955), but the inland was settled as well (Noe-Nygaard 1983; 1987; Madsen 1986). In the Åmosen region of Sjælland, Denmark, for example, about 100 inland Ertebølle sites are known (Andersen 1983). However, inland sites have not received the same attention as coastal sites (Blankholm 2008; Thorpe 1996). Inland settlement may have been scarce at the beginning of the EBK, but increased during the later EBK (Dellbrügge 2002; Fischer 1993; 2002b; Schilling 1997; 2003). Inland sites were generally smaller and settled for shorter periods of time than coastal sites (Andersen 1993), although larger inland sites are also known (Petersen 1987). The Danish sites Vester Ulslev and Godsted, for example, both situated on small islands in lakes, were exclusively summer sites, but represent large occupational units (Petersen 1973).

At inland sites, a wide variety of freshwater resources was exploited. Cultural layers at Mesolithic sites in the Åmose bog area contain bones and scales from freshwater fish and shells from freshwater molluscs. The site of Præstelyngen, for example, was dominated by pike bones (Noe-Nygaard 1983; 1987). The significance of freshwater resources for the Ertebølle culture is demonstrated by the efforts put into the construction of stationary fishing devices. Around Ringkloster in Jutland, fish fences made of long and slender hazel stakes were found. Together with pollen evidence, this indicates the coppicing of hazel (Andersen 1994-95).

In Schleswig-Holstein, the Rivers Trave, Alster, Bille and Stecknitz were important locations for fishing and hunting stations from the Mesolithic to the Bronze Age (Schirren 1997). The Satruper Moor, a former lake at the Bondenau River, provides another example of a concentration of sites (Schwabedissen 1960). Artefacts found at inland sites attest freshwater fishing: e.g. leisters, netfloats and nets from the sites Rüde 2 and Förstermoor in Schleswig-Holstein (Schwabedissen 1960; 1980).

Aquatic plants might also have formed an important part of Mesolithic nutrition, although they are less visible archaeologically than freshwater fish and molluscs. There is evidence for the collection of water chestnuts, water-lily seeds and reed mace (Tilley 1996; Holst 2010). The favoured Mesolithic settlement sites at lagoons, estuaries, shallow lakes and fen carrs might have been chosen for their wealth of rhizomes and tubers (Tilley 1996).

Handmade pottery first appears in this region in the later EBK (c. 4500-4000 cal BC), in two forms: a flat, elliptical bowl interpreted as a lamp, and a deep, open vessel with a pointed 
base and a decorated rim, regarded as a cooking pot (Hartz 2011). Biomolecular analysis of absorbed lipids confirms that pottery was used for these purposes, and a significant proportion of pots tested have produced biomarkers associated with aquatic species (Heron et al. 2013; Craig et al. 2011).

\subsection{Stable isotope signals of aquatic foods}

Microscopic and biomolecular analyses provide qualitative evidence of the function of pottery; isotopic analyses produce quantitative data, which can provide information about the exploitation of different food resources to the extent that there is variation in isotope values between foods. In palaeodietary studies, the stable isotope ratios $\delta^{13} \mathrm{C}$ and $\delta^{15} \mathrm{~N}$ in human bone collagen are often used to estimate the contribution of aquatic food sources within the diet, as both $\delta^{13} \mathrm{C}$ and $\delta^{15} \mathrm{~N}$ are generally higher in marine fish than in terrestrial foods; $\delta^{34} S$ is also increasingly used for this purpose. Freshwater fish also tends to be enriched in $\delta^{15} \mathrm{~N}$, while $\delta^{13} \mathrm{C}$ values are often lower than in terrestrial foods, so in principle stable isotopes can be used to estimate the dietary contribution of freshwater resources. In animals, isotopic fractionation (differential retention of different isotopes) leads to higher $\delta^{15} \mathrm{~N}$ values at each level in the food chain (which is why the longer aquatic food chains can be distinguished isotopically), but $\delta^{15} \mathrm{~N}$ is relatively consistent in different tissues. Values of $\delta^{13} \mathrm{C}$ vary significantly between bone collagen and other tissues, but when collagen $\delta^{13} \mathrm{C}$ values alone are compared, only minor isotopic enrichment from dietary species to consumers is evident.

Many cooking pots retain amorphous black surface deposits that are usually described as burnt food crusts. Very rarely do such deposits contain identifiable remains (e.g. fish scales), but starch grains and phytoliths show that terrestrial plants were sometimes among the ingredients (Saul et al. 2012). Lipids extracted from food crusts can also be attributed to foods cooked or stored in the same pots, and may contain biomarkers of aquatic or terrestrial animal products (Craig et al. 2011). Isotopic techniques could be used to analyse food crusts, provided that fractionation during cooking, charring and burial is insignificant. In addition, the concentrations of $\mathrm{C}$ and $\mathrm{N}$, which are often measured during stable isotope analysis, can be used to interpret food crusts to the extent that they vary between ingredients and are not altered by cooking or diagenesis.

Experiments with modern ingredients show that measurements of $\delta^{13} \mathrm{C}$ and $\delta^{15} \mathrm{~N}$ and $\mathrm{C}$ and $\mathrm{N}$ concentrations in burnt food crusts are reasonably consistent with values expected from those in the original uncooked ingredients, indicating that charring does not destroy the isotopic and elemental abundance signals of different food groups (Philippsen 2013a; Philippsen et al. 2012; Philippsen in press). Moreover, the pattern of stable isotope data 
seen in a large number of archaeological food crusts from the south-west Baltic region suggests that isotopic signals of food ingredients are not significantly altered during burial (Figure 1): food crusts from coastal sites often give 'marine' isotope values (enriched $\delta^{13} \mathrm{C}$ and $\delta^{15} \mathrm{~N}$ ), while those from inland sites often give 'freshwater' values (depleted $\delta^{13} \mathrm{C}$, enriched $\delta^{15} \mathrm{~N}$ ). The clear division between coastal and inland sites is also evidence that fish were cooked regularly, since terrestrial food resources would not be isotopically distinct.

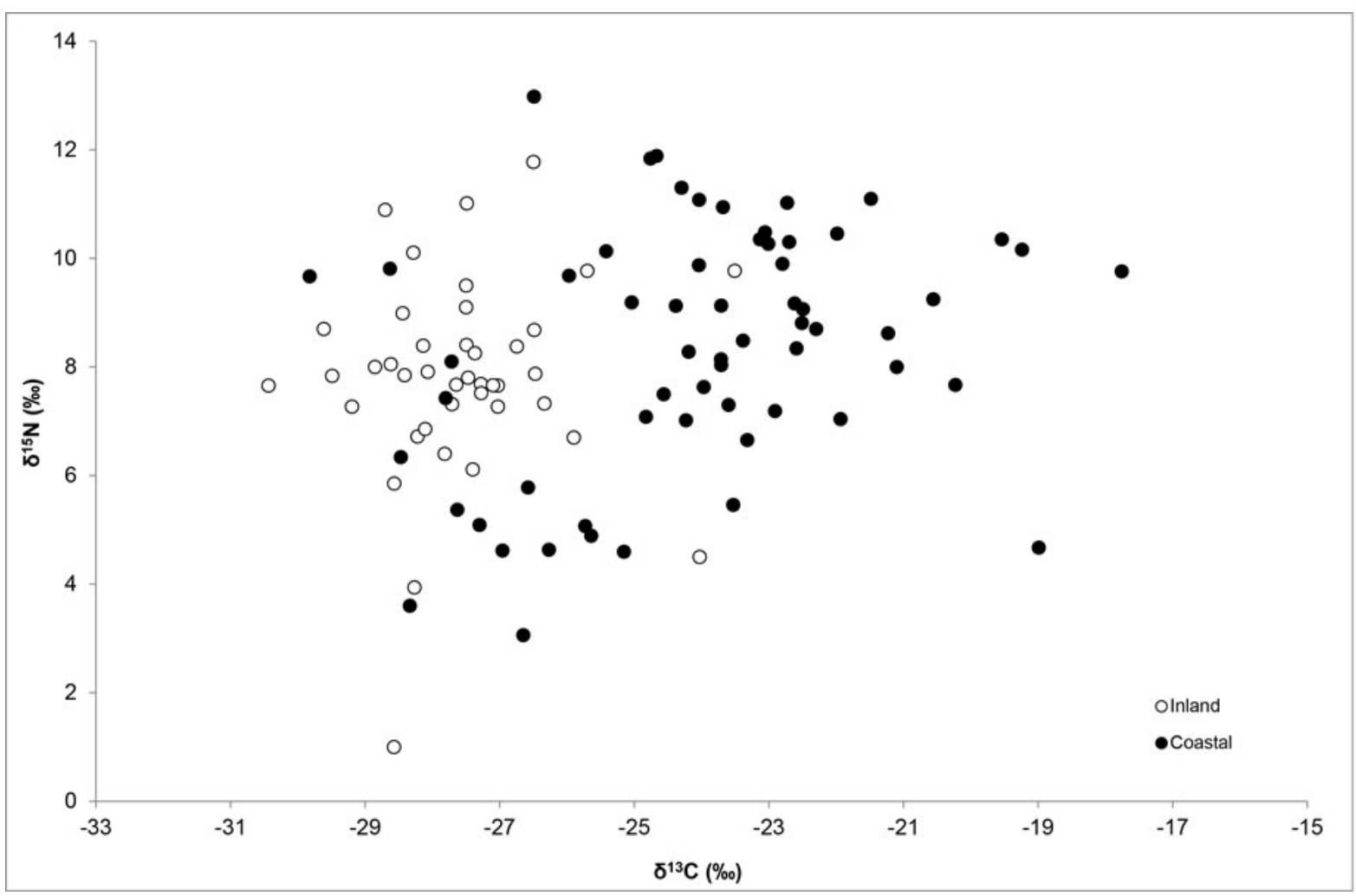

Figure 1: $\delta^{13} \mathrm{C}$ and $\delta^{15} \mathrm{~N}$ measurements on bulk food-crust samples from late Mesolithic and early Neolithic pottery, sites in eastern Denmark and Schleswig-Holstein, Germany (based on Craig et al. 2011, fig. 2)

Biomolecular analysis confirms that freshwater resources were prepared in pottery. At the inland site of Ringkloster in Jutland, for example, $14 \%$ of the vessels had aquatic (freshwater) lipid biomarkers (Craig et al.2011). Pottery from the Åmose contained aquatic biomarkers (Craig et al. 2007), and the isotopic values of the fatty acids suggest that the residues were derived from freshwater fish (Heron et al. 2007). Biomolecular analysis underestimates the proportion of pots used to cook fish, however, as distinctive biomarkers are not always preserved, and biomarker presence/absence data provide little indication of how much fish was cooked relative to terrestrial food resources. Furthermore, pottery from sites in the Trave and Alster valleys has not been analysed by these methods.

Human remains are scarce in this region during the late Mesolithic, but finds of freshwater mollusc shells as well as very negative $\delta^{13} \mathrm{C}$ values in human and dog bones suggest an 
especially high dependence on freshwater food during the Mesolithic-Neolithic transition (Fischer et al. 2007).

\subsection{Radiocarbon and aquatic foods}

Burnt food crusts are often dated by radiocarbon $\left({ }^{14} \mathrm{C}\right)$, avoiding questionable associations between archaeological pottery and other datable materials that might be found in proximity (Segerberg et al. 1991; Hallgren and Possnert 1997; Hallgren 2008), but several authors have noted that food crust ${ }^{14} \mathrm{C}$ ages may be subject to ${ }^{14} \mathrm{C}$ reservoir effects, if pots are used to cook fish (Persson 1999; Fischer 2002b; Fischer and Heinemeier 2003). Reservoir effects can arise when the base of the food chain is not photosynthesis of atmospheric $\mathrm{CO}_{2}$, but of $\mathrm{CO}_{2}$ dissolved in water (DIC, or dissolved inorganic carbon). In freshwater systems, large reservoir effects usually come from the dissolution of limestone by rainwater (hardwater systems). Some DIC is formed by mineralisation of DOC (dissolved organic carbon), which originates from e.g. the erosion of old soil and peat beds, which can cause reservoir effects in soft-water systems (Olsson 1983; 1996). Aquatic plants and phytoplankton use DIC in photosynthesis, which transfers reservoir effects into the aquatic food chain. Living plants and animals from Alster and Trave, for example, can have apparent ${ }^{14} \mathrm{C}$ ages of up to $2000-$ 3000 years (Philippsen and Heinemeier 2013).

Experimental food crusts made from these organisms have similar ${ }^{14} \mathrm{C}$ ages, and there are cases in this region where archaeological food crusts give ${ }^{14} \mathrm{C}$ ages that are much older than expected, but within the range predicted for fish contemporary with the pottery (Philippsen 2010; Philippsen et al. 2010; 2012).

\section{Materials and Methods}

\subsection{Study region and sites}

All the sites discussed in this article are located in Germany's northernmost federal state, Schleswig-Holstein. Schlamersdorf LA 5, Bebensee LA 76 and Seedorf LA 245 are located in the Trave valley, Kayhude LA 8 in the Alster valley (Figure 2). The shortest distance between the rivers is $c .20 \mathrm{~km}$. Both rivers flow through a moraine landscape. The Trave, which only drains upper moraines (from the Weichselian glaciation), flows into the Baltic at Lübeck. The Alster runs between upper and lower moraines (the latter from the Saale glaciation) and meets the Elbe River at Hamburg. The glacial till (Geschiebemergel) in the upper moraines contains c. $20 \%$ calcium carbonate, while the glacial sand in the lower moraines (Geschiebesand) only contains 0-5\% calcium carbonate (Stewig 1982, and references therein). Both Trave and Alster today have carbonate-rich (hard) water. 


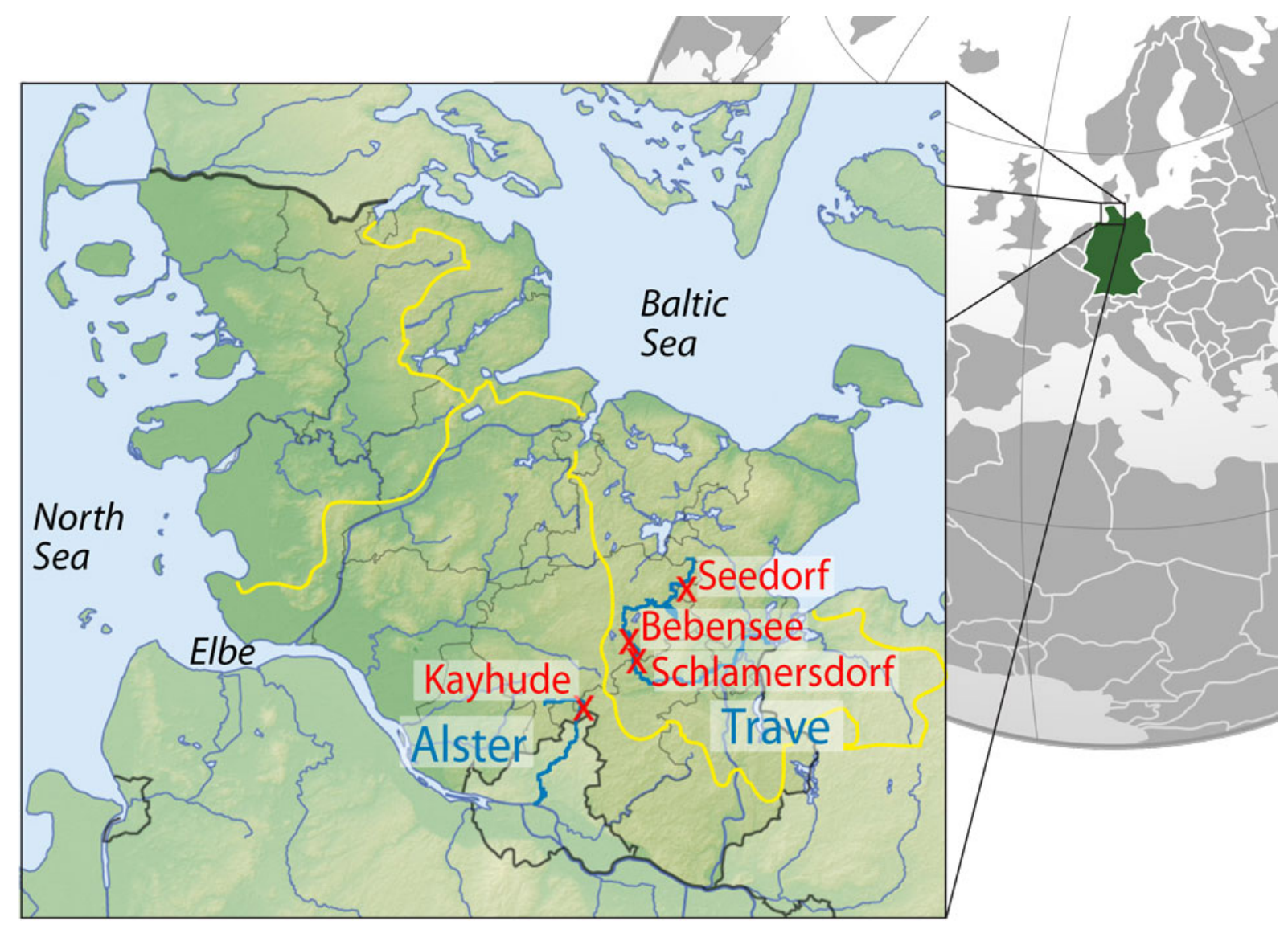

Figure 2: Map of the study region. The sites Schlamersdorf LA 5, Bebensee LA 76, Seedorf LA 245 and Kayhude LA 8 are indicated by red crosses. Main watersheds are indicated by yellow lines (after Umweltbundesamt 2004). Map of Schleswig-Holstein by Wikimedia user NordNord-West, relief by Wikimedia user Lencer, globe by Wikimedia user TheEmirr

\subsubsection{Trave valley: Schlamersdorf, Bebensee, Seedorf}

Schlamersdorf lies in a $2 \mathrm{~km}$-long, $700 \mathrm{~m}$-wide section of the Trave valley, which narrows to $200 \mathrm{~m}$ at the north and south. The site discussed here is Schlamersdorf LA 5, situated on a low spit of land that reached into the former lake or river. Despite the large number of flint tools found at Schlamersdorf (Hartz 1996; 1997), there is no evidence that they were made on site (Heinrich 1993), which supports the interpretation that Schlamersdorf was a specialised hunting or fishing station. There were bones from at least eleven individuals of waterfowl, one wild boar, two red deer and one aurochs, and smaller mammals like wildcat, European otter, European beaver and red squirrel (Heinrich 1993). The fish-bone assemblage is dominated by Northern pike (Esox lucius). Other important fish are cyprinids (Cyprinidae) and European perch (Perca fluviatilis). Ten pointed wooden poles were probably part of a stationary fishing device (Hartz 1996). Some natural depressions in the peat were filled with remains of freshwater mollusc shells, which can be interpreted as food refuse. The same phenomenon is known from other sites such as those in the Åmosen, or from Bebensee LA 76 (Hartz 1993). 
Lübke (2000) provides a comprehensive description of the sites Bebensee LA 26 and LA 76. Bebensee LA 76, discussed here, lies on an island in a former lake of the Trave valley. It was discovered in 1977 and excavated 1988-1991. The site was occupied repeatedly from the late Mesolithic to the early Neolithic, with finds of EBK and Funnel-Beaker pottery, and occasional later finds. According to pottery decoration, most sherds should belong to a late EN I horizon. Red deer, aurochs, wild boar and roe deer dominate the faunal remains, while most fish-bones belong to pike, catfish and cyprinids. Swan mussels (Anodonta cygnea) were also identified. About $20 \%$ of faunal remains are from domestic animals, but all evidence points towards the EBK site being a temporary hunting and fishing station.

Seedorf lies on the western edge of the Heidmoor bog, through which the Trave flows. At a former lake, sites of various Mesolithic and Neolithic cultures were discovered (Bokelmann 1994; 1999). Food crusts from two of these, LA 245 and LA 296, have been dated; the potsherds themselves were not diagnostic, but the sites seem to have been occupied most intensively in the late Mesolithic (Hartz 2011).

\subsubsection{Alster valley: Kayhude}

Kayhude is situated $15 \mathrm{~km}$ north of Hamburg, in a narrow flood plain. Fens north and south of the site are likely to be former lakes, while the river itself was about $50 \mathrm{~m}$ wide in the past and often changed its course (Ingo Clausen, pers. comm. 2007). An area of $80 \mathrm{~m}^{2}$ was excavated in 2005/2006 by Schleswig-Holstein's state office for archaeology and 1500 finds, among them 70 potsherds, were retrieved from what had been a discard zone in shallow open water. Other finds included antler axes, wooden tools, a stone mace head, pot boilers, and bone and antler remains from wild animals (Clausen 2007). The faunal assemblage included pike, perch and pond turtle (Clausen 2008). An 8m-long row of wooden poles, each up to $70 \mathrm{~cm}$ long, can be interpreted as a fish weir, dated to around $5000 \mathrm{cal} \mathrm{BC}$. Inundations of the Alster disturbed the stratigraphy, so it is difficult to identify associated artefacts. Only those finds from a seemingly undisturbed stony layer at the bottom (Ingo Clausen, pers. comm. 2007) are discussed here.

\subsection{Samples and laboratory methods}

Eight food crusts from Seedorf LA 245 and 23 from Bebensee LA 76 were radiocarbon-dated in the 1990s at the Leibniz-Labor, Kiel, following Nadeau et al. (1998), by the excavators, Klaus Bokelmann and Jürgen Hoika. Any remaining material from these food crusts (held by the laboratory or the Schleswig-Holstein State Archaeological Museum, Schloss Gottorf) was sampled for stable isotope analysis in 2011-12. Samples from Schlamersdorf and Kayhude were analysed as part of B. Philippsen's PhD project. A variety of clearly terrestrial and clearly aquatic samples, in addition to several food crusts, was dated from each site. 
Note 1: There are other ${ }^{14} \mathrm{C}$ ages from Bebensee LA 76, including six food crust results from the Utrecht laboratory (Hartz 2011, table 2), which are generally under 5000 BP. Several bones date to the Funnel-Beaker period, while others appear to date to the early (pre-ceramic) Ertebølle period. Nevertheless, some diagnostic Ertebølle pottery was recorded.

Most of the potsherds with food crusts at these sites are not typologically diagnostic, and their attribution to Ertebølle or Funnel Beaker cultures on the basis of radiocarbon dates is hazardous, given the potential for large ${ }^{14} \mathrm{C}$ reservoir effects. Indeed, all four food crusts dated from diagnostic Funnel-Beaker sherds at Bebensee gave ${ }^{14} \mathrm{C}$ ages greater than 5300 $\mathrm{BP}$, when the Funnel-Beaker tradition would normally be dated to $5000 \mathrm{BP}$ or later (Andersen 1986; 1990, Fischer 2002a; Hartz and Lübke 2006; Glykou 2011). Radiocarbon ages under 5000 BP can only be associated with Funnel-Beaker (or later) pottery, but older ${ }^{14} \mathrm{C}$ ages from undiagnostic sherds in mixed deposits might represent either FunnelBeaker or Ertebølle pottery (and given the predominance of late Funnel-Beaker pottery types among the diagnostic sherds at Bebensee, it is unlikely that many of the dated food crusts are from Ertebølle sherds). Eight samples were available for stable isotope analysis, including one of those from a diagnostic Funnel-Beaker sherd and three that gave ${ }^{14} \mathrm{C}$ ages under $5000 \mathrm{BP}$; the other four are potentially from Ertebølle sherds [Note 1].

Note 2: It is unclear whether the four Funnel-Beaker samples from the same square metre and depth represent four different vessels. Three ${ }^{14} \mathrm{C}$ ages of food crusts from unidentified potsherds from an adjacent site, Seedorf LA 296, were reported by the excavator (Bokelmann 1994: $5690 \pm 65$ BP (OxA-4481, $\delta^{13} \mathrm{C}=-27.7 \%$ ), $5835 \pm 70 \mathrm{BP}\left(\mathrm{OxA}-4483, \delta^{13} \mathrm{C}=26.6 \%\right.$ ) and $5935 \pm 65 \mathrm{BP}\left(\mathrm{OxA}-4482, \overline{\delta^{13} \mathrm{C}}=26.1 \% \mathrm{o}\right)$ ). Another food crust from Seedorf was dated previously: (OxA-4016, 5160 $\pm 70 B P, \delta^{13} C=-31.3$ : Hedges et al. 1993). It is unclear whether this sample was from LA 245, LA 296, or another site at Seedorf.

The Seedorf LA 245 samples were clustered in two areas of the site - five samples with very similar ${ }^{14} \mathrm{C}$ ages, of late Funnel-Beaker date, were from one small area, and three potentially Ertebølle dates are from samples found 11-12m away at a lower depth [Note 2]. Three of the younger food crusts and all three of the older samples were available for analysis. Most other ${ }^{14} \mathrm{C}$ samples from Seedorf LA 245 were from bone or antler artefacts found in other parts of the site, and these are typically much older or younger than the food crusts, but a bone awl was dated to the late Ertebølle period and could be contemporary with the older food crusts.

At Schlamersdorf, evidence including ${ }^{14} \mathrm{C}$ ages of terrestrial samples (charcoal and bones) confirms that the Funnel-Beaker and Ertebølle occupations are spatially distinct, and at the LA 5 location it is likely that we are only dealing with Ertebølle pottery. Only Ertebølle pottery was recorded at Kayhude, and ${ }^{14} \mathrm{C}$ dates of worked wood and antler samples (as well as the typology of these artefacts) all belong to the later Mesolithic period (Clausen 2007). 
Note 3: Where both untreated sample material and Kiel's ${ }^{14} \mathrm{C}$ dating extract were analysed, we report only the extract results. Unpublished EA-IRMS data on dating extracts from coastal sites in Schleswig-Holstein are generally consistent with those reported by Craig et al. (2011), who analysed untreated food crusts from the same assemblages. Post-depositional carbonates and organics removed by acid-alkali-acid pretreatment should be carbon-rich and nitrogen-poor, but we found no systematic difference in $\mathrm{C} / \mathrm{N}$ values between extracts and untreated samples of the same food crusts $(n=15)$.

For ${ }^{14} \mathrm{C}$ dating, food crust samples were pre-treated by the normal acid-alkali-acid method (e.g. Olsson 1976); $1 \mathrm{M} \mathrm{HCl}$ at $80^{\circ} \mathrm{C}$ for one hour, $1 \mathrm{M} \mathrm{NaOH}$ at $80^{\circ} \mathrm{C}$ for at least three hours and $1 \mathrm{M} \mathrm{HCl}$ at $20^{\circ} \mathrm{C}$ overnight, although the $\mathrm{NaOH}$ concentration and temperature was reduced to 0.5 or $0.2 \mathrm{M}$ at room temperature for archaeological food crusts. In a few cases, food crusts were treated using a sequence of solvents (Bruhn et al. 2001) before acid-alkaliacid extraction, although there is no evidence that this affected either the ${ }^{14} \mathrm{C}$ ages or stable isotope results. For EA-IRMS (Elemental Analysis-Isotope Ratio Mass Spectrometry), the extract used for ${ }^{14} \mathrm{C}$ dating was analysed where possible. Stable isotope measurements of extracts and untreated food crust samples show no systematic differences, and results are usually close (differences $<1-2 \%$ ). Discrepancies between repeat measurements from a single sherd appear to be related more to lack of homogeneity in the food crusts themselves than to differences in sample preparation [Note 3].

The food crusts from Schlamersdorf and Kayhude were analysed at the AMS ${ }^{14} \mathrm{C}$ Dating Centre at Aarhus University, by combustion in a EuroVector elemental analyser coupled to an IsoPrime stable isotope ratio mass spectrometer. Most samples yielded enough material for doublet measurements. Food crust samples from Bebensee and Seedorf were analysed by Dr Ulrich Struck at the Berlin Natural History Museum, using a THERMO/Finnigan MAT V isotope ratio mass spectrometer, coupled to a THERMO Flash EA 1112 elemental analyser. $\delta^{13} \mathrm{C}$ values are reported as \% VPDB, $\delta^{15} \mathrm{~N}$ values as \% AIR. Atomic $\mathrm{C} / \mathrm{N}$ ratios were derived from $\% \mathrm{C}$ and $\% \mathrm{~N}$ measurements.

\section{Results}

Table 1 and Figure 3 show the stable isotope data for food crusts from the four sites. The two isotopes are apparently correlated, with high $\delta^{15} \mathrm{~N}$ corresponding to more depleted $\delta^{13} \mathrm{C}$ values, consistent with our expectation that freshwater fish was one of the ingredients cooked regularly in these pots. The results must be interpreted with caution, however. Food crusts may represent the remains of a single meal, but still contain multiple ingredients. Experimental cooking suggests that some starchy plant food may be required to produce a thick layer of burnt food. In this case the ${ }^{14} \mathrm{C}, \delta^{13} \mathrm{C}$ and $\mathrm{C} / \mathrm{N}$ values may primarily reflect those in a plant ingredient, while $\delta^{15} \mathrm{~N}$ may be determined mainly by a fish ingredient. Our $\mathrm{C} / \mathrm{N}$ values are typically $8-16$, too high for most animal products and too low for most plants, 
suggesting a mixture of ingredients. Cooking, burning and diagenesis might also affect the concentrations of different components (protein, carbohydrate, fat, fibre), which could alter the stable isotope and $\mathrm{C} / \mathrm{N}$ values - although in practice these effects seem to be very modest (Philippsen 2013b; Fernandes et al. 2014). Carbon in fat is depleted in $\delta^{13} \mathrm{C}$ compared to that in carbohydrate or protein, so high fat content should shift food-crust $\delta^{13} \mathrm{C}$ towards more aquatic values, but while it would not affect $\delta^{15} \mathrm{~N}$, it would dramatically raise the $\mathrm{C} / \mathrm{N}$ value, and we see no evidence of this in our results. So we are confident that we can interpret $\delta^{13} \mathrm{C}$ values below c. $-27 \%$ as evidence of freshwater fish, particularly if $\delta^{15} \mathrm{~N}$ is above 6\% (low trophic level aquatic foods (e.g. mussels) would be depleted in $\delta^{15} \mathrm{~N}$ and $\left.\delta^{13} \mathrm{C}\right)$.

\begin{tabular}{|c|c|c|c|c|c|c|c|c|}
\hline Site & Sample & Lab. code & $\delta^{13} \mathrm{C}$ & $\delta^{15} \mathrm{~N}$ & $\% \mathrm{~N}$ & $\% \mathrm{C}$ & $\begin{array}{c}\text { atomic } \\
\mathrm{C} / \mathrm{N}\end{array}$ & ${ }^{14} \mathrm{C}$ age \\
\hline Bebensee & Beb7619770089 & KIA-411 & 29.8 & 6.9 & 6.7 & 63.9 & 11.2 & $6285 \pm 40$ \\
\hline Bebensee & Beb7619770094 & KIA-412 & 30.5 & 8.3 & 6.2 & 47.3 & 8.9 & $6195 \pm 40$ \\
\hline Bebensee & Beb7619770213 & KIA-416 & 29.3 & 7.5 & 6.3 & 64.4 & 11.9 & $5770 \pm 40$ \\
\hline Bebensee & Beb7619770215 & KIA-417 & 26.8 & 6.6 & 5.5 & 64.6 & 13.7 & $5345 \pm 35$ \\
\hline Bebensee & 76-1977/0088 & KIA-250 & $\begin{array}{l}- \\
26.0\end{array}$ & 6.8 & 3.8 & 63.7 & 19.8 & $5335 \pm 35$ \\
\hline Bebensee & 26-1991/0394 & KIA-248 & 27.2 & 5.5 & 1.0 & 10.7 & 12.9 & $4695 \pm 60$ \\
\hline Bebensee & Beb7619890658 & KIA-421 & 27.9 & 7.9 & 6.8 & 61.9 & 10.7 & $4860 \pm 50$ \\
\hline Bebensee & Beb7619770216 (a) & KIA-418 & $\begin{array}{l}- \\
28.0\end{array}$ & 3.7 & 0.4 & 75.0 & 244.4 & $4765 \pm 35$ \\
\hline
\end{tabular}




\begin{tabular}{|c|c|c|c|c|c|c|c|c|}
\hline $\begin{array}{l}\text { Seedorf LA } \\
245\end{array}$ & $\begin{array}{l}\text { N 20,08 E 98,94 x- } \\
1,66\end{array}$ & KIA-281 & $\begin{array}{l}- \\
30.9\end{array}$ & 7.0 & 5.2 & 49.0 & 11.0 & $5980 \pm 60$ \\
\hline $\begin{array}{l}\text { Seedorf LA } \\
245\end{array}$ & $\begin{array}{l}\text { N 22,59 E 99,80 x- } \\
2,03\end{array}$ & KIA-282 & $\begin{array}{l}- \\
29.1\end{array}$ & 4.6 & 4.9 & 45.5 & 10.8 & $5830 \pm 35$ \\
\hline $\begin{array}{l}\text { Seedorf LA } \\
245\end{array}$ & $\begin{array}{l}\text { N 22,55 E 99,82 x- } \\
2,04\end{array}$ & KIA-280 & $\begin{array}{l}- \\
28.6\end{array}$ & 5.6 & 6.5 & 60.6 & 10.9 & $5720 \pm 35$ \\
\hline $\begin{array}{l}\text { Seedorf LA } \\
245\end{array}$ & $\begin{array}{l}\text { N 13,13 E } 97,13 x- \\
1,38\end{array}$ & KIA-283 & $\begin{array}{l}- \\
25.7\end{array}$ & 5.5 & 6.5 & 49.7 & 8.9 & $4345 \pm 40$ \\
\hline $\begin{array}{l}\text { Seedorf LA } \\
245\end{array}$ & $\begin{array}{l}\text { N 11,91 E 96,23 x- } \\
1,23\end{array}$ & KIA-277 & $\begin{array}{l}- \\
24.7\end{array}$ & 4.4 & 4.0 & 52.1 & 15.3 & $4310 \pm 35$ \\
\hline $\begin{array}{l}\text { Seedorf LA } \\
245\end{array}$ & $\begin{array}{l}\text { N 11,45 E 96,70 x- } \\
1,24\end{array}$ & KIA-284 & $\begin{array}{l}- \\
24.5\end{array}$ & 4.0 & 4.6 & 50.0 & 12.6 & $4245 \pm 40$ \\
\hline Schlamersdorf & SLA5-2683 & $\begin{array}{l}\text { AAR- } \\
14211\end{array}$ & $\begin{array}{l}- \\
33.0\end{array}$ & 6.9 & 3.8 & 41.1 & 12.1 & $6871 \pm 35$ \\
\hline Schlamersdorf & SLA5-1713 & $\begin{array}{l}\text { AAR- } \\
11481\end{array}$ & $\begin{array}{l}- \\
28.0\end{array}$ & 3.4 & 0.4 & 8.8 & 16.3 & $6850 \pm 120$ \\
\hline Schlamersdorf & SLA5-2707 & $\begin{array}{l}\text { AAR- } \\
11482\end{array}$ & $\begin{array}{l}- \\
27.0\end{array}$ & - & 1.1 & 7.3 & 13.0 & $5590 \pm 110$ \\
\hline Schlamersdorf & SLA5-1802 & $\begin{array}{l}\text { AAR- } \\
11484\end{array}$ & $\begin{array}{l}- \\
27.5\end{array}$ & - & 0.5 & 5.5 & 14.9 & $5950 \pm 170$ \\
\hline Kayhude & KAY8-432,01 & $\begin{array}{l}\text { AAR- } \\
11403\end{array}$ & $\begin{array}{l}- \\
28.4\end{array}$ & 7.0 & 8.5 & 60.5 & 8.8 & $5695 \pm 55$ \\
\hline Kayhude & KAY8-168,01 & $\begin{array}{l}\text { AAR- } \\
11404\end{array}$ & $\begin{array}{l}- \\
28.9\end{array}$ & 12.5 & 8.1 & 56.9 & 8.3 & $6090 \pm 55$ \\
\hline Kayhude & KAY8-412.01 & $\begin{array}{l}\text { AAR- } \\
11479\end{array}$ & $\begin{array}{l}- \\
26.5\end{array}$ & 6.4 & 2.9 & 43.5 & 17.8 & $5350 \pm 110$ \\
\hline
\end{tabular}




\begin{tabular}{|l|l|l|l|l|l|l|l|l|}
\hline Kayhude & KAY8-435 & $\begin{array}{l}\text { AAR- } \\
14212\end{array}$ & $\begin{array}{l}- \\
26.7\end{array}$ & - & - & 5.1 & 15.5 & $5948 \pm 35$ \\
\hline
\end{tabular}

Note 4: The three Funnel-Beaker sherds from Bebensee that could not be re-sampled for stable isotopes gave AMS $\delta^{13} \mathrm{C}$ values of -30 to $-32 \%$, and ${ }^{14} \mathrm{C}$ ages of $5800-6100 \mathrm{BP}$, similar to those of the most depleted 'unknown' samples in Figure 3. We therefore cannot be certain that any of the Bebensee food crusts are associated with Ertebølle pottery.

The most terrestrial isotopic values $\left(\delta^{13} \mathrm{C} c .-24\right.$ to $-26 \%, \delta^{15} \mathrm{~N}$ under $6 \%$ o) are all associated with early Neolithic Funnel-Beaker pottery, and with the lowest ${ }^{14} \mathrm{C}$ ages. It is of course plausible that terrestrial foods became more important during the early Neolithic, but the differences in ${ }^{14} \mathrm{C}$ ages between Funnel-Beaker food crusts with aquatic and terrestrial stable isotope signatures could also be explained by the scale of ${ }^{14} \mathrm{C}$ reservoir effects in the Trave and Alster [Note 4]. Aside from the date range of the assemblages concerned, variability in freshwater reservoir effects between individual aquatic organisms from the Trave and Alster (Philippsen and Heinemeier 2013) may explain why there is not a clearer correlation between stable isotopes and ${ }^{14} \mathrm{C}$ ages (Figure 3): unlike isotope data from human bone, food-crust isotope signatures may reflect single cooking events, and should therefore capture more of the isotopic variability in an ecosystem.

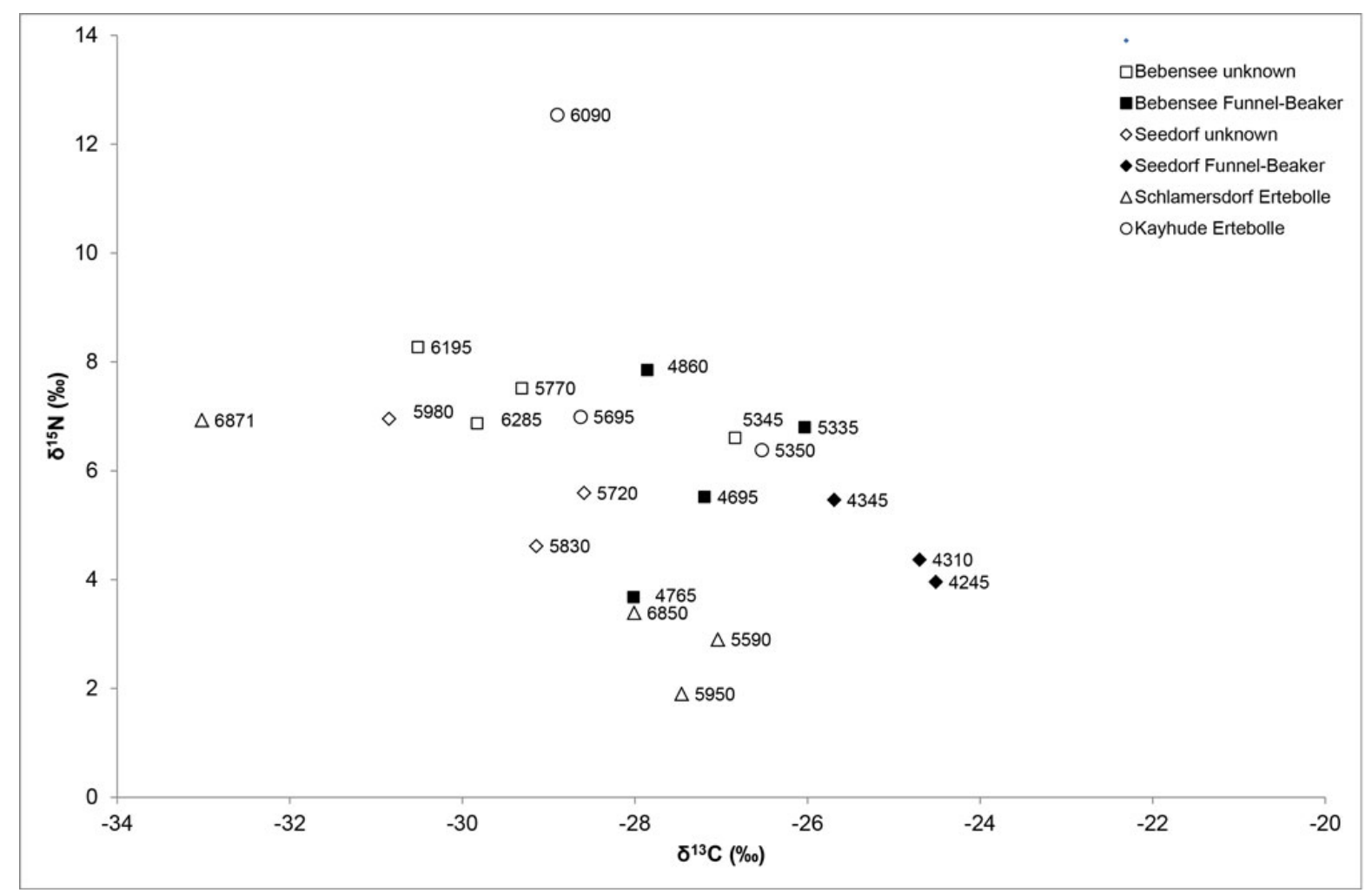


Figure 3: Stable isotope results from food crusts, Trave and Alster valley sites (squares, Bebensee; diamonds, Seedorf; triangles, Schlamersdorf; circles, Kayhude); filled symbols, samples that must be from early Neolithic Funnel-Beaker pottery, based on sherd typology or ${ }^{14} \mathrm{C}$ age; empty symbols, samples from Ertebølle pottery (or undetermined). Labels indicate conventional ${ }^{14} \mathrm{C}$ ages of food crusts (Stuiver and Polach 1977), which can incorporate large reservoir effects (expected conventional ${ }^{14} \mathrm{C}$ ages for terrestrial samples: late Ertebølle c. 5700-5200 BP, Funnel-Beaker 5100$4300 \mathrm{BP})$.

Note 5: 95\% confidence intervals for the calibrated dates were calculated using OxCal v4 (Bronk Ramsey 2009) and the IntCal13 calibration curve (Reimer et al. 2013).

Schlamersdorf LA 5 provides the best opportunity to investigate the use of pottery for cooking fish in the late Mesolithic. Terrestrial ${ }^{14} \mathrm{C}$ samples span most of the Ertebølle period

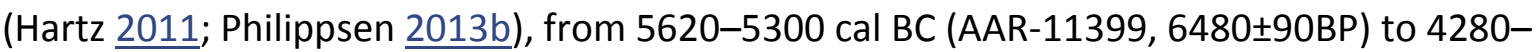

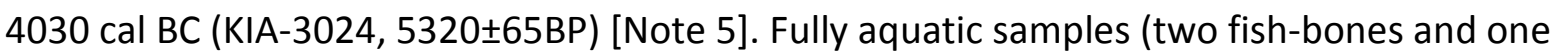
mollusc) have conventional ${ }^{14} \mathrm{C}$ ages greater than $7500 \mathrm{BP}$. One sherd contains external sooting from the cooking fire, which would date the pot towards the end of the Ertebølle period (AAR-11481S, $5190 \pm 110 \mathrm{BP}$ ). The food crust from the same sherd is $1660 \pm 160{ }^{14} \mathrm{C}$ years older, despite its relatively terrestrial stable isotope values $\left(\delta^{13} \mathrm{C}=-28.0\right.$ and $\left.\delta^{15} \mathrm{~N}=3.4\right)$. Even if most of the carbon in this food crust is from aquatic sources, with reservoir effects of this magnitude, the Schlamersdorf fish-bone and mollusc samples would not be older than the fully terrestrial samples, and it would only require a $20-60 \%$ carbon contribution from aquatic sources (i.e. a reservoir effect of 330-1000 years, given the results for AAR-11481) for all six food crusts from this site to date to after c. 4500 cal BC (c. 5700 BP). The fishbones and mollusc samples dated would, however, belong to the early-middle Ertebølle period, which is also represented by several charcoal and mammal bone radiocarbon samples.

\section{Discussion}

Stable isotope data demonstrate a systematic difference in food-crust $\delta^{13} \mathrm{C}$ between coastal and inland sites in the Ertebølle and Funnel-Beaker periods, which is consistent with the $\delta^{13} \mathrm{C}$ differences between marine and freshwater fish in this region. Analyses of absorbed lipids in pottery and food-crust samples from the coastal sites confirm that marine mammals or fish were regularly cooked in Ertebølle pots (e.g. Craig et al. 2011) and that the practice was maintained in the early Neolithic Funnel-Beaker culture. There are no lipid analyses from inland Ertebølle sites in Schleswig Holstein, and the stratigraphic association between pottery and other evidence of the exploitation of freshwater resources (e.g. fishbones, fishing fences) at these sites is unsatisfactory. Moreover, we have no human remains 
for stable isotope analysis. The scale of freshwater reservoir effects in these rivers thus means that it is possible for food-crust dates to be highly misleading.

The isotopic data from food crusts are therefore important evidence of the prevalence of fish consumption at inland sites in the late Ertebølle period. It is only possible to compare Ertebølle food crusts to Funnel-Beaker food crusts, as we have no data for foods eaten raw or cooked without the use of pottery. While some of the Funnel-Beaker food crusts appear to be $100 \%$ terrestrial in origin, most or even all of the Erteb $\varnothing$ lle food crusts have an aquatic signature.

Note 6: In addition to the observation above that most Funnel-Beaker sherds at Bebensee were typologically late $\mathrm{EN} \mathrm{I}$, there are several unpublished ${ }^{14} \mathrm{C}$ ages from terrestrial samples c. 4700-4600 BP (i.e. second half of the 4th millennium).

The radiocarbon ages of the food crusts are consistent with this interpretation, when we consider the scale of freshwater reservoir effects in modern samples from the Trave and Alster (Philippsen and Heinemeier 2013). Food crusts on Funnel-Beaker sherds at Bebensee LA 76, which are unlikely to be older than the mid-4th millennium cal $B C$, gave ${ }^{14} \mathrm{C}$ ages of up to $6100 \mathrm{BP}$, meaning reservoir effects in some cases of more than $1000{ }^{14} \mathrm{C}$ years [Note 6]. Applying similar corrections to the 'oldest' ${ }^{14} \mathrm{C}$ ages for Erteb $\varnothing$ lle food crusts at Schlamersdorf and Kayhude would imply that pottery did not appear in the Trave and Alster valleys until c. $5700 \mathrm{BP}$ (c. $4500 \mathrm{cal} \mathrm{BC}$ ). At several coastal sites in East Holstein there is Ertebølle pottery that apparently dates to the second half of the 5th millennium cal BC, and not earlier (Hartz 2011); thus the apparently 'older' dates for pottery from inland sites may simply reflect the fact that reservoir effects in freshwater fish are much greater than those in marine fish and mammals.

\section{Conclusion}

Stable isotope and radiocarbon measurements clearly separate food crusts on Ertebølle pottery found at inland sites in the Trave and Alster valleys from food crusts on similar pottery from sites on the Baltic coast of Schleswig-Holstein. The only reasonable explanation of this pattern is that at the inland sites (and probably also at coastal sites) pottery was regularly, perhaps mainly, used to cook fish and other aquatic resources. Evidence from modern reference material shows that fish from the Trave and Alster Rivers are much more depleted in both ${ }^{13} \mathrm{C}$ and ${ }^{14} \mathrm{C}$ than marine fish, and that experimentally charred food crusts retain the isotopic signatures of the ingredients. We therefore contend that there is no scientific evidence that pottery was used in the Trave and Alster valleys before the mid-5th millennium cal BC, and that it is the frequency with which Ertebølle people cooked fish 
which creates the impression that pottery from inland sites is earlier than that from coastal sites.

\section{Acknowledgements}

EA-IRMS measurements of the Bebensee and Seedorf samples were funded by the Zentrum für Baltische und Skandinavische Archäologie, Stiftung Schleswig-Holsteinische Landesmuseen, Schloss Gottorf. Claus von Carnap-Bornheim, Stiftung SchleswigHolsteinische Landesmuseen, Schloss Gottorf, financed 30 of the radiocarbon dating for B. Philippsen's research, and the foundation 'Prof. Werner Petersen-Stiftung' in Kiel, Germany, provided the funds.

\section{Bibliography}

Andersen, K. 1983 Stenalderbebyggelsen i den Vestsjællandske Åmose, Copenhagen: Fredningsstyrelsen.

Andersen, S.H. 1986 'De forhistoriske tider på Aggersborgegnen' in F. Nørgaard, E. Roesdahl and R. Skovmand (eds) Aggersborg gennem 1000 år. Fra vikingeborg til slægtsgård, Herning: Poul Kristensens Forlag. 29-52.

Andersen, S.H. 1990 'Limfjordens forhistorie - en oversigt', Limfjordsprojektet: Rapport nr 1, 29-65.

Andersen, S.H. 1993 'Kystens bopladser' in S. Hvass and B. Storgaard (eds) Da klinger i Muld... 25 års arkæologi i Danmark, Århus: Aarhus Universitetsforlag. 65-69.

Andersen, S.H. 1994-95 'Ringkloster', Journal of Danish Archaeology 12, 13-59.

Blankholm, H.P. 2008 'Southern Scandinavia' in G. Bailey and P. Spikins (eds) Mesolithic Europe, Cambridge: Cambridge University Press. 107-31.

Bokelmann, K. 1994 'Frühboreale Mikrolithen mit Schäftungspech aus dem Heidmoor im Kreis Segeberg', Offa51, 37-47.

Bokelmann, K. 1999 'Interkulturelle Kontakte. Zum Beginn des Spätmesolithikums in Südskandinavien. Geweihaxt, Dreieck und Trapez, 6100 cal BC', Offa 56, 183-197.

Bronk Ramsey, C. 2009 'Bayesian analysis of radiocarbon dates', Radiocarbon 51, 337-60. 
Bruhn, F., Duhr, A., Grootes, P.M., Mintrop, A. and Nadeau, M.-J. 2001 'Chemical removal of conservation substances by "Soxhlet"-type extraction', Radiocarbon 43(2A), 229-37.

Clausen, I. 2007 'Steinzeitliches Alstervergnügen', Archäologie in Deutschland 2, 54.

Clausen, I. 2008 'Von späten Jägern und frühen Bauern...', Archäologische Nachrichten aus Schleswig-Holstein14, 14-16.

Craig, O.E., Forster, M., Andersen, S.H., Koch, E., Crombé, P., Milner, N., Stern, B., Bailey, G.N. and Heron, C. 2007 'Molecular and isotopic demonstration of the processing of aquatic products in Northern European prehistoric pottery', Archaeometry 49, 135-

52. http://dx.doi.org/10.1111/j.1475-4754.2007.00292.x

Craig, O.E., Steele, V.J., Fischer, A., Hartz, S., Andersen, S.H., Donohoe, P., Glykou, A., Saul, H., Jones, D.M., Koch, E. and Heron, C.P. 2011 'Ancient lipids reveal continuity in culinary practices across the transition to agriculture in Northern Europe', Proceedings of the National Academy of Sciences of the United States of America 108, 17910-

15. http://dx.doi.org/10.1073/pnas.1107202108

Dellbrügge, S.B. 2002 Steinzeitliche Knochen- und Geweihfunde im nördlichen SchleswigHolstein, Bonn: Dr Rudolf Habelt GmbH.

Fernandes, R., Meadows, J., Dreves, A., Nadeau, M.-J. and Grootes, P.M.M. 2014 'A preliminary study on the influence of cooking on the $\mathrm{C}$ and $\mathrm{N}$ isotopic composition of multiple organic fractions of fish (mackerel and haddock)', Journal of Archaeological Science. http://dx.doi.org/10.1016/j.jas.2014.07.006

Fischer, A. 1993 'Mesolithic inland settlement' in S. Hvass and B. Storgaard (eds) Digging into the Past. 25 Years of Archaeology in Denmark, Århus: Aarhus Universitetsforlag. 58-63.

Fischer, A. 2002a 'Editorial introduction to the papers' in A. Fischer and K. Kristiansen (eds) The Neolithisation of Denmark. 150 Years of Debate, Sheffield: J.R. Collis Publications. 3-8.

Fischer, A. 2002b 'Food for feasting? An evaluation of explanations of the neolithisation of Denmark and southern Sweden' in A. Fischer and K. Kristiansen (eds) The Neolithisation of Denmark. 150 Years of Debate, Sheffield: J.R. Collis Publications. 341-394.

Fischer, A., and Heinemeier, J. 2003 'Freshwater reservoir effect in ${ }^{14} \mathrm{C}$ dates of food residue on pottery', Radiocarbon 45, 449-66.

Fischer, A., Olsen, J., Richards, M., Heinemeier, J., Sveinbjörnsdottir, Á.E. and Bennike, P. 2007 'Coast-inland mobility and diet in the Danish Mesolithic and Neolithic: evidence from 
stable isotope values of humans and dogs', Journal of Archaeological Science 34, 212550. http://dx.doi.org/10.1016/i.jas.2007.02.028

Gjessing, G. 1955 'Veiding og sanking i førhistorisk tid i norden' in S. Erixon (ed) Fångst, jakt och fiske, Nordisk kultur. no. 11/12A, Stockholm, Oslo, København: Albert Bonniers Förlag, H. Aschehoug and Co.s Forlag, J.H. Schultz Forlag. 1-63.

Glykou, A. 2011 Neustadt - ein submariner Fundplatz des späten Mesolithikums und frühesten Neolithikums in Schleswig-Holstein. Untersuchungen zur Subsistenzstrategie der letzten Jäger, Sammler und Fischer an der norddeutschen Ostseeküste, Dissertation, Christian-Albrechts-Universität zu Kiel.

Hallgren, F. 2008 Identitet i praktik. Lokala, regionala och överregionala sociala sammanhang inom nordlig trattbägarkultur, Uppsala, Coast to Coast project, Department of Archaeology and Ancient History, Uppsala University.

Hallgren, F. and Possnert. G. 1997 'Pottery design and time. The pottery from the TRB site Skogsmossen, in view of the AMS-datings of organic remains on potsherds', Tor 29, 113-36.

Hartz, S. 1993 'Inland-Ertebølle in Schleswig-Holstein. Die Fundstelle Schlamersdorf LA5, Kr. Stormarn' in D. Meier (ed) Archäologie in Schleswig 1/1991 [Symposium Wohlde], Kiel. 3338.

Hartz, S. 1996 'Zehnter Arbeitsbericht des Archäologischen Landesamtes Schleswig-Holstein. Grabungsberichte der Jahre 1988-1993: Travenbrück (Altgemeinde Schlamersdorf), Kr. Stormarn, Steinzeitliche Wohnplätze Travenbrück, LA5 und LA15', Offa 53, 374-78.

Hartz, S. 1997 'Ertebøllekultur im Travetal. Ausgrabungen auf dem Fundplatz Travenbrück LA 5 (Gemarkung Schlamersdorf), Kreis Stormarn. Ein Vorbericht' in 'Denkmalpflege im Kreis Stormarn III', Stormarner Hefte 20, 171-86.

Hartz, S. 2011 'From pointed bottom to round and flat bottom - tracking early pottery from Schleswig-Holstein' in S. Hartz, F. Lüth and T. Terberger (eds) Early Pottery in the BalticDating, Origin and Social Context, Berichte der Römisch-Germanischen Kommission 89. 24176.

Hartz, S. and Lübke, H. 2006 'New evidence for a chronostratigraphic division of the Ertebølle culture and the earliest Funnel Beaker Culture on the Southern Mecklenburg Bay' in C.-J. Kind (ed) After the Ice Age. Settlements, subsistence and social development in the Mesolithic of Central Europe, Stuttgart: Konrad Theiss Verlag. Materialhefte zur Archäologie in Baden-Württemberg. 59-74. 
Hedges, R.E., Housley, R.A., Bronk Ramsey, C. and Van Klinken, G. 1993 'Radiocarbon dates from the Oxford AMS system: Archaeometry datelist 17', Archaeometry 35(2), 305-

26. http://dx.doi.org/10.1111/j.1475-4754.1993.tb01046.x

Heinrich, D. 1993 'Die Wirbeltierreste vom ellerbekzeitlichen Siedlungsplatz Schlamersdorf LA5, Kreis Stormarn', Zeitschrift für Archäologie 27, 67-89.

Heron, C., Craig, O.E., Forster, M., Stern, B. and Andersen, S.H. 2007 'Residue analysis of ceramics from prehistoric shell middens in Denmark: initial investigations at Norsminde and Bjørnsholm' in N. Milner, O.E. Craig and G.N. Bailey (eds) Shell Middens in Atlantic Europe, Oxford: Oxbow Books. 78-85.

Heron, C., Andersen, S., Fischer, A., Glykou, A., Hartz, S., Saul, H., Steele, V. and Craig, O. 2013 'Illuminating the Late Mesolithic: residue analysis of "blubber" lamps from Northern Europe', Antiquity 87, 178-88.

Holst, D. 2010 'Hazelnut economy of early Holocene hunter-gatherers: a case study from Mesolithic Duvensee, northern Germany', Journal of Archaeological Science 37, 287180.http://dx.doi.org/10.1016/j.jas.2010.06.028

Lübke, H. 2000 Die steinzeitlichen Fundplätze Bebensee LA 26 und LA 76, Kreis Segeberg. Band I: Die Steinartefakte, Technologisch-ergologische Studien zum Nordischen Frühneolithikum, Neumünster: Wachholtz Verlag.

Madsen, T. 1986 'Where did all the hunters go? An assessment of an epoch-making episode in Danish prehistory', Journal of Danish Archaeology 5, 229-39.

Nadeau, M.-J., Grootes, P.M., Schleicher, M., Hasselberg, P., Rieck, A. and Bitterling, M. 1998 'Sample throughput and data quality at the Leibniz-Labor AMS facility', Radiocarbon 40(1), 239-45.

Noe-Nygaard, N. 1983 'The importance of aquatic resources to Mesolithic man at inland sites in Denmark' in C. Grigson, and J. Clutton-Brock (eds) Animals and Archaeology 2: Shell middens, fishes and birds, Oxford: British Archaeol. Rep. Int. Ser. 183. 125-142.

Noe-Nygaard, N. 1987 'Taphonomy in archaeology with special emphasis on man as a biasing factor', Journal of Danish Archaeology 6, 7-52.

Olsson, I.U. 1976 'The importance of the pretreatment of wood and charcoal samples' in R. Berger and H.E. Suess (eds) Radiocarbon Dating - ninth international conference. Los Angeles and La Jolla: University of California Press. 135-146. 
Olsson, I.U. 1983 'Dating non-terrestrial materials' in Hackens T, Mook WG, Waterbolk HT (eds) Proceedings of ${ }^{14} \mathrm{C}$ and Archaeology, Groningen, the Netherlands 1981 (PACT 8). 27794.

Olsson, I.U. $1996{ }^{114} \mathrm{C}$ dates and the reservoir effect' in J. Van Der Plicht, and J.-M. Punning (eds) International Workshop on Isotope-Geochemical Research in the Baltic Region, Lohusalu, Estonia, March 14-16, 1996, Groningen, The Netherlands: Centre for Isotope Research, Faculty of Mathematics and Natural Sciences, University Groningen. 5-23.

Persson, P. 1999 Neolitikums början. Undersökningar kring jordbrukets introduktion i Nordeuropa, Göteborg: Institutionen för Arkeologi.

Petersen, E.B. 1973 'A survey of the Late Palaeolithic and Mesolithic of Denmark' in S.K. Kozłowski (ed) The Mesolithic in Europe, Warsaw: Warsaw University Press. 77-129.

Petersen, E.B. 1987 'Late Palaeolithic and Mesolithic', Arkæologiske udgravninger i Danmark, 79-81.

Philippsen, B. 2010 'Terminal Mesolithic diet and radiocarbon dating at inland sites in Schleswig-Holstein' in Kiel Graduate School 'Human Development in Landscapes' (ed) Landscapes and Human Development: The Contribution of European Archaeology: Proceedings of the International Workshop 'Socio-Environmental Dynamics over the Last 12,000 Years: The Creation of Landscapes' (1-4 April 2009), Bonn: Dr. Rudolf Habelt GmbH. 21-36.

Philippsen, B. 2013a 'Der Süßwasser-Reservoireffekt in der ${ }^{14} \mathrm{C}$-Datierung: neue Analysen und mesolithische Kochexperimente', Experimentelle Archäologie in Europa - Bilanz (2013), 20-32.

Philippsen, B. 2013b 'The freshwater reservoir effect in radiocarbon dating', Heritage Science 1, 24. http://dx.doi.org/10.1186/2050-7445-1-24

Philippsen, B. in press 'Isotopic analyses of food crusts on pottery: implications for dating and palaeocuisine reconstructions' in Proceedings of the workshop 'Contact and TransitionFrom late hunter-gatherers to early farmers in coastal and inland environments", Greifswald, 14-15 December 2012.

Philippsen, B. and Heinemeier, J. 2013 'Freshwater reservoir effect variability in Northern Germany',Radiocarbon 55, 1085-101. http://dx.doi.org/10.2458/azu is rc.55.16065

Philippsen, B., Kjeldsen, H., Hartz, S., Paulsen, H., Clausen, I. and Heinemeier, J. 2010 'The hardwater effect in AMS ${ }^{14} \mathrm{C}$ dating of food crusts on pottery', Nuclear Instruments and 
Methods in Physics Research Section B: Beam Interactions with Materials and Atoms 268, 995-98. http://dx.doi.org/10.1016/j.nimb.2009.10.082

Philippsen, B., Glykou, A. and Paulsen, H. 2012 'Kochversuche mit spitzbodigen Gefäßen der Ertebøllekultur und der Hartwassereffekt' in U. Weller, T. Lessig-Weller, E. Hanning and B. Strugalla-Voltz (eds) Experimentelle Archäologie in Europa - Bilanz, Unteruhldingen, Europäische Vereinigung zur Förderung der Experimentellen Archäologie/European Association for the advancement of archaeology by experiment e.V.

Reimer, P.J., Bard, E., Bayliss, A., Beck, J.W., Blackwell, P.G., Bronk Ramsey, C., Grootes, P.M., Guilderson, T.P., Haflidason, H., Hajdas, I., Hatte, C., Heaton, T.J., Hoffmann, D.L., Hogg, A.G., Hughen, K.A., Kaiser, K.F., Kromer, B., Manning, S.W., Niu, M., Reimer, R.W., Richards, D.A., Scott, E.M., Southon, J.R., Staff, R.A., Turney, C.S.M., van der Plicht, J. 2013 'IntCal13 and Marine13 radiocarbon age calibration curves $0-50,000$ years cal BP', Radiocarbon 55, 1869-1887. http://dx.doi.org/10.2458/azu is rc.55.16947

Saul, H., Wilson, J., Heron, C.P., Glykou, A., Hartz, S. and Craig, O.E. 2012 'A systematic approach to the recovery and identification of starches from carbonised deposits on ceramic vessels', Journal of Archaeological Science 39, 3483-

92. http://dx.doi.org/10.1016/j.jas.2012.05.033

Schilling, H. 1997 'På sporet af stenalderens jægere og fiskere i Sydsjællands indland', Kulturhistoriske Studier (1997), 27-37.

Schilling. H. 2003 'Early Mesolithic settlement patterns in Holmegårds Bog on South Zealand, Denmark' in Lars Larsson, Hans Kindgren, Kjel Knuttson, David Loeffler, Agneta Åkerlund (eds) Mesolithic on the Move. Papers presented at the Sixth International Conference on the Mesolithic in Europe, Oxbow Books, Oxford. 351-358.

Schirren, C.M. 1997 Studien zur Trichterbecherkultur in Südostholstein, Bonn: Dr. Rudolf Habelt GmbH.

Schwabedissen, H. 1960 'Die Ausgrabungen im Satruper Moor', Offa 16, 5-28.

Schwabedissen, H. 1980 'Ertebølle/Ellerbek - Mesolithikum oder Neolithikum?', Veröffentlichungen des Museums für Urgeschichte Potsdam 14/15, 129-42.

Segerberg, A., Possnert, G., Arrhenius, B. and Lidén, K. 1991 'Ceramic chronology in view of ${ }^{14} \mathrm{C}$ datings', Laborativ Arkeologi 5, 83-91.

Stewig, R. 1982 Landeskunde von Schleswig-Holstein, Berlin, Stuttgart: Gebrüder Borntraeger. 
Stuiver, M. and Polach, H.A. 1977 'Discussion. Reporting of ${ }^{14} \mathrm{C}$ data', Radiocarbon 19, 35563.

Thorpe, I.J. 1996 The Origins of Agriculture in Europe, London: Routledge.

Tilley, C. 1996 An Ethnography of the Neolithic. Early prehistoric societies in southern Scandinavia, Cambridge: Cambridge University Press. 